underlie unconformably strata containing what he be lieved to be Lower Silurian fossils. It is not improbable, however, that they belong to an older time than any of the Cambrian rocks of Wales.

That the red sandstones of the north-west of Scotland were laid down in shallow water seems to be clearly indicated by their current-bedding and ripple-marks, as well as by the occurrence of bands of conglomerate among them on many successive horizons. Yet they retain these characters throughout a depth of some Io,000 feet. We can walk over their edges and count every successive stratum for a thickness of more than 3000 feet along the sides of a single mountain. How then, could such a continuous mass of shallow-water deposits be accumulated? I am not sure that any wholly satisfactory answer can be given to this question, which is one that arises in the investigation of various epochs of geological history. That the basins must have been due to local subsidence can hardly be doubted. We may suppose that this downward movement continued at the same time that the ridges which bounded the hollows continued to be forced upward. New shore-lines would thus be brought to the level of the water, and coarse shingle might be swept down upon previously deposited fine sediment. If occasionally the barrier between the basins and the open sea were partially submerged, the muddy ferruginous water of the inclosed tracts might be cleared out, and the denizens of the sea might for a time enter them. Possibly the grey and dark shales may mark these irruptions of the ocean.

That similar conditions of geography prevailed at that period in the extreme north-west of Europe is indicated by the fact that in Norway a group of red sandstones and conglomerates, known as the "sparagmite rocks," is interposed between the Archrean gneiss and the oldest of the fossiliferous formations. In these Scandinavian rocks we probably see traces of the extension of similar inclosed water-basins along the eastern border of the primæval Atlantic Ocean northwards among the hollows of the Archæan land.

Before the next great geological period these basins had been entirely effaced, and the geography of the region had wholly changed. This transformation is probably traceable to two causes. First, the terrestrial movements which led to the formation and continuance of the basins may in the end have caused their extinction by raising them into land, and possibly at the same time by folding and fissuring their accumulated deposits. Secondly, as soon as these deposits, whether split open or not, were exposed to the atmosphere they would begin to be worn down. That erosion took place during a prolonged period, and to a vast extent, is shown by the fact that in some places the thick cake of sandstone was hollowed out down to the Archæan platform below it before the next succeeding formations were deposited. Here again we are presented with a striking example of the imperfection of the geological record.

(To be continued.)

\section{THE PRIVATE LABORATORY OF MARINE ZOOLOGY AT RAPALLO.}

THIS very modest zoological station does not in the least pretend to compete with the splendid ones of Naples, Plymouth, Roscoff, Banyuls, \&c. Considerable sums are needed to build and keep up such establishments, so that their numbers will necessarily be always very limited.

We have thought that with relatively little expense it might be possible for zoologists to procure in great part the advantages that these larger stations offer, and to concur in their action, by establishing a certain number of small stations on favourable spots of the Italian coast.
Our idea is to have dependencies of the zoological laboratories of the nearest Universities, almost as if parts of those laboratories were transported to the sea-shore The cost of these stations would not be very great All that is strictly necessary is a room with good light, and as near as possible to the sea, provided with small aquariums, with the usual pump, with fishing apparatus, and the ordinary furniture of every laboratory, except microscopes and other costly instruments, which every investigator would bring with him. The books also might be reduced to the treatises and the "Faunæ" ordinarily used. It is indispensable that the station should possess at least one boat for short excursions: for deep dredging, and for longer excursions that are less often made, the necessary vessels could be hired.

By these modest means notable results night be obtained. Almost all anatomical and histological researches would be possible, the inquirer either making them entirely on the spot, or limiting his work to the first observations that ought to be made on specimens freshly caught, and preparing the materials for later and more leisurely study.

Stations of this sort already exist abroad, such as the laboratory of marine zoology of Wimereux, the Netherlands movable station, the station of Misaki in Japan, \&c.

In Italy, Prof. Kleinenberg proposed to found a station of this kind at Messina, but of greater proportions, hoping that it might serve principally as a school for beginners; but unfortunately his idea has not yet been realized. Neither has anything come of the project of Count Alessandro Ninni to establish a station at Venice that might serve at the same time for purely scientific researches, and for practical studies on the industrial cultivation of sea animals.

Convinced of the utility of small stations, we have made an experiment in forming one which we will now describe.

Unwilling to go too far from Turin, we have chosen the little town of Rapallo on the Eastern Riviera, near Genoa. It is situated at the end of the gulf of the same name, is one hour's distance by boat from Portofino, that marks the extremity of the gulf towards Genoa. The Gulf of Rapallo is pretty well sheltered from the winds; the shores are rather rocky, and vegetable and animal life is very various and abundant. It also presents notable variations of depth. From Rapallo to the extremity of the gulf, a distance of 4 kilometres, the depth gradually reaches 90 metres, and at a like distance in the open sea of Portofino, the depth is more than 400 metres. The movement in the haven is limited, and hence the waters even near the town are clear. As to the town, it is beautifully situated, and the neighbouring places are various and very pleasant. It is also a very quiet town, where the greatest liberty can be enjoyed.

Our station occupies a space of a hundred square metres, and it is placed a few metres from the sea, on the ground where the docks formerly stood. In this space, inclosed by a wooden palisade, is the little building which looks like a chalet, the lower part in brick-work, with wooden walls and a roof covered with zinc. The edifice consists of only one large room, 7 metres in length, and 4.50 in width (inside). The height up to the wooden ceiling, that is under the roof, is about 4 metres. One of the longer walls is turned to the north. A window, consisting of nine large divisions, runs the whole length of this wall; and against this wall is placed the workingtable, which also occupies the whole length; at it six persons can work. The door is on the shorter side that looks on the sea; over the door is placed the reservoir of sea-water capable of containing more than 800 litres; it is filled by a small rotatory pump. By means of pipes the water is brought from this reservoir into the aquariums that are placed in the middle of the 
room on an iron support of two stories, provided with the necessary discharge-pipes to carry off the water that has circulated in the aquariums. Against the shortest wall, opposite that in which the door is placed, there is a table covered with porcelain for chemical manipulations. Above this table there is a reservoir of fresh water. In the middle of the room, behind the support of the aquariums, are two tables covered with marble. Against the wall opposite the window are the shelves for the instruments and for the collections. One corner is set apart for the principal fishing implements.

The station has a boat, the Bonellia, that serves for short excursions, and for researches in shallow water. The fishing implements consist principally of trawlnets for the depth, nets for surface fishing, apparatus for extracting masses from the bottom, sieves, nets, harpoons, \&c. These implements have been made expressly at Naples, under the supervision of Dr. Paolo Mayer, of the Zoological Station.

The station is also provided with numerous aquariuns for study, and with the necessary chemical apparatus. The library is limited to the more common and useful treatises, and to a certain number of memoirs concerning the marine fauna.

We hope that even by these simple means it will be possible to obtain satisfactory results. Many important works on marine zoology have been produced far away from zoological stations under less favourable conditions than those of our little station.

$$
\text { Zoological Museum, Turin. } \quad \text { D. RosA. }
$$

\section{WEISMANN ON THE INHERITANCE OF} INJURIES. ${ }^{1}$

I $\mathrm{N}$ an address to the Naturforscher-Versammlung at Cologne, last autumn (now published in a compact pamphlet of fifty-two pages), Dr. Weismann examined the evidence for the inheritance of injuries. In earlier works he has shown that the facts of organic evolution can be explained without the hypothesis of the inheritance of acquired characters, and his theory of the germ-plasma as the basis of heredity is hardly compatible with the traditional and Lamarckian view. The supporters of the old view have laid great stress upon the transmission of the effects of injuries. A great many of the cases relied on rest on merely anecdotal evidence, and Weismann examines and dismisses many types of them. Such, for instance, is the case adduced by Dr. Zacharias, and quoted by Eimer, of a tailless cat which produced tailless kittens. Nothing whatever of how the mother lost her tail is known, and nothing is known of the father. Tailless kittens appcaring suddenly in villages have been traced, more than once, to an imported male of one of the many tailless breeds. In any particular case, it is as logical to refer the appearance of tailless kittens to a hypothetical mutilation of the mother, as it would be to deduce from the many-toed Oxford cats that Mr. Poulton had fixed additional toes on the paws of their ancestor!

Weismann made an elaborate series of experiments on mutilation. On October 17, I 887 , he had the tails removed from seven female and five male white mice. On November 16 the first brood appeared. These, and all subsequent broods, were removed from the cage. Up to December I 7, 1888, 333 young were born, and in none of them was there any sign of the mutilation being inI "Ueber die Hypothese einer Vererbung von Verletz"ngen." Visn Dr,
August Weismann, Professor in Freiburg i. Br. Uena: Gustav Fischer,
(889) herited. In cage 2, fifteen young, of December 2, 1887, were placed, their tails having been removed. These, up to December 17, 1888, produced 233 young, all with normal tails. In cage 3 , fourteen young of the second generation, with tails removed, were placed; and up to December 17, I888, they produced I4I young, all quite normal. The experiment was carried, with a negative result, down through five generations of mutilated animals. The length of tail of new-born mice varies from I0.5 millimetres to 12 millimetres. In the series of experiments, 849 young were produced by mutilated progenitors, and in no case was a mouse produced with its tail less than 10.5 millimetres.

The author points out that, while it might be said that experiments through a far greater number of generations were needed, the so-called cases of inheritance of mutilation all imply that the mutilation is impressed on the immediately following generations. A mother breaks her finger, and her daughter has the joint of the corresponding finger imperfect. A cow has her horn torn off, and, in due course, gives birth to a one-horned calf.

Moreover, there are many cases of mutilations which have been made for hundreds of years without result. For instance, Settegast shows that all the crows but the rook have bristly feathers on their beaks. Rooks, too, have these feathers while nestlings; but, later on, they lose them by perpetually pushing the beak into the ground in search of food.

There are a great many cases which at first sight appear to prove the inheritance of injuries. As an example of how easy it is to be deceived, Weismann relates that a friend bad a vertical scar (with comb-like striæ) on the left ear, the result of a sword-wound. On the left ear of this gentleman's daughter was a curiously similar marking. But it was ultimately noticed that on the right ear of the father was an appearance precisely similar to that on the left ear of the daughter. On closer examination of the father's left ear there was seen, under the scar, a linear streak, from which the strix ran, forming a comblike structure. It was this, doubtless a congenital variation, and not the accidental scar, that the daughter had inherited.

It is impossible to give, by extracts, an adequate conception of Dr. Weismann's ingenious analysis and masterly collation of evidence. There is enough in it to satisfy the most conservative of biologists (at least without a theory) that the transmission of injuries must be handed for ever to the "scientific novelist" and the jaded melodramatist. With them it may flourish, and rescue many a doubtful heir, and secure the happiness of many a heroine in the third volume, or before the curtain falls.

It is not so certain that all will admit Weismann's contention that the demolition of the inheritance of injuries furnishes strong presumptive evidence that acquired characters are not inherited. It might well be urged that there is a great distinction between characters which are obviously not useful (such as injuries) and useful characters. It is clear that if acquired characters are inherited it would be of the highest utility if the inheritance were selective. The tiny piece of ancestral germ-plasma increases exceedingly during the ontogeny. Has the distinction between germ-plasma and somatic plasma passed sufficiently out of the region of theory to let us infer, from the non-reflection of injuries during the process of growth, that all acquired characters are not reflected? Can we hold that, were acquired characters reflected, injuries too must be reflected? It is a question, on the one hand, of the nice adjustment of fine probabilities; on the other, of elaborate, long-continued, and specially directed observation. But, whatever is the final answer of science, this essay will be not the least of the author's many valuable contributions to it.

$$
\text { P. C. M. }
$$

